\title{
Pensonomonoor
}

2017, vol. 77, 77-90

http://dx.doi.org/10.12657/denbio.077.007

\author{
Martin Šrámek, Václav Hurt, Jan Čermák
}

\section{Above- and below-ground tree parameters and their development after modelling of thinning in young elm stands}

Received: 6 April; Accepted: 27 January 2017

\begin{abstract}
During the last century almost two-thirds of all elms were lost due to the Dutch elm disease. Therefore, elms are an endangered species with a lasting lack of knowledge about ecosystem functions of elms in forest stands. The study describes several above- and below-ground tree parameters and their changes after simulation of thinning in one young forest stand with dominant Ulmus laevis Pall. in the Czech Republic. The distribution of the leaves was measured using the 'cloud' technique. The absorptive root area was measured with the aid of the modified earth impedance method to evaluate below-ground tree parameters. Using allometric equations, it was possible to calculate certain tree parameters of individual trees as well as the entire forest stand. The modelling of four thinning intensities (low, medium, high and very high) helped to establish the changes of these tree parameters after treatment. The leaf area index of the stand was 5.6, the absorptive root area index was 1.7 and the total biomass of foliage was $8.5 \mathrm{Mg} \mathrm{ha}^{-1}$ prior to the treatment. The absorptive root area amounted to $30 \%$ of the foliage area. The exponential models were developed to predict the above- and below-ground tree parameters. Under the different thinning intensities, the following were found: a negative correlation with the number of trees for the leaf area index, the foliage biomass and the absorptive root area index. This knowledge is important in the process of maintaining the presence of endangered elms in forest stands and in ecosystem services (e.g. carbon storage) throughout Europe.
\end{abstract}

Keywords: elm, leaf area, absorptive root area, biomass, thinning

Addresses: M. Šrámek, Department of Forest Botany, Dendrology and Geobiocoenology, Mendel University in Brno, Zemědělská 3, 61300 Brno, Czech Republic, e-mail: martin.sramek@mendelu.cz V. Hurt, Department of Silviculture, Mendel University in Brno, Zemědělská 3, 61300 Brno, Czech Republic

J. Cermák, Department of Forest Botany, Dendrology and Geobiocoenology, Mendel University in Brno, Zemědělská 3, 61300 Brno, Czech Republic 


\section{Introduction}

Elms have high economic, environmental and social value and they are important components of European forests (Hemery et al., 2010). During the last century, there was a significant decline in elms caused by the Dutch elm disease (Webber \& Gibbs, 1984; Barbosa \& Wagner, 1989; Jassim et al., 1990; Brasier, 1991; Santini et al., 2008). Forest stands comprising mainly elm have become very rare due to this disease. Nowadays the share of elm is $0.02 \%$ in the Czech Republic (MZe, ČR, 2006) and 1\% in the German state of Saxony (Mackenthun, 2013). Breeding programmes have selected hybrids resistant to the Dutch elm disease for ornamental purposes and knowledge in this field is sufficient. However, knowledge about the above- and below-ground parameters of elms in the forest is lacking.

The vertical leaf distribution and the leaf area index (LAI) are important parameters of the structure, function and health of forest stands, communities and ecosystems (Vose et al., 1995; Čermák, 1998; Kull et al., 1999). Leaf distribution influences many auto-ecological and ecosystem functions, such as gas exchange within the crown, the interception of irradiance and precipitation, nutrient availability, stand productivity, stand microclimate and the mechanical stability of trees and stands (Kellomäki et al., 1985; Baldocchi et al., 1986; Thimonier et al., 2010). Accurate estimates of forest tree biomass are growing in importance. In view of climate change, scientists are starting to consider all tree biomass parts - for both their energy and carbon content (Nabuurs et al., 2002). Although foliage biomass is not the most important biomass pool of the forest ecosystem in terms of quantity, it has a high turnover rate compared with other biomass pools, e.g. branches or stem, and so foliage litter is often the most important above-ground source of carbon input into the soil (Lehtonen, 2005). Foliage biomass is difficult to predict because of its great variation and dependence on various site and tree properties. As a consequence, direct measurements, which are laborious and involve destructive sampling, are often needed (e.g. Hoffmann \& Usoltsev, 2002; Liski et al., 2002; Masera et al., 2003). Tree biomass equations are the basic tool for converting inventory plot data into the quantity of biomass (Lambert et al., 2005).

The underground parts of trees, i.e. roots and their functional features (such as the absorptive root area, ARA), are as important as the above-ground parts for understanding the function and general living conditions of trees and stands in forest ecosystems. The root system performs very important functions, including the absorption, transport and storage of nutrients (Schulze et al., 1983; Körner, 1994). One of the fundamental parameters of trees is the active ion absorptive root area, a parameter that is comparable to leaf area. The absorptive root area can be measured using the modified earth impedance method, which was developed for this purpose (Staněk, 1997; Aubrecht et al., 2006). Measurement of the absorptive root area index (RAI) is important for characterising the capacity of roots to absorb and conduct water (Čermák et al., 2013a) and provides a way of characterising ecosystem functioning as a physiologically meaningful index of the below-ground absorbing area (Butler et al., 2010). The relation between actual absorptive root area and foliage area probably plays an important role in plant survival. The estimation of RAI permits a comparison with LAI and therefore an evaluation of the RAI:LAI ratio, which can be understood as a structural tree balance. This is a very important parameter (applied very frequently, e.g. in agriculture) that often indicates the probability of tree survival under unfavourable environmental conditions (Sperry et al., 1998).

Management of forest stands has a significant effect on the evolution of above- and below-ground tree parameters. Knowledge of above- and below-ground tree parameters after thinning enables the obtaining of information about forest stand evolution. Therefore, this paper also describes above- and below-ground tree parameters after thinning.

The aims of this study are as follows: 1) to describe and quantify the amount and the vertical spatial distribution of foliage; 2) to describe the amount of the absorptive root area and foliage biomass of a young elm forest stand; 3) to provide the necessary scaling-up tools and allometric equations which can be applied for the calculation of leaf area, foliage biomass and absorptive root area; 4) to indicate the response of leaf area index, absorptive root area index and foliage biomass to thinning. As such, this study expands on the previous paper (Šrámek \& Čermák, 2012) covering a detailed study of the vertical leaf distribution of European White Elm.

\section{Materials and methods}

\section{Experimental site - location, soil and climate}

The research site is situated near the floodplain forest in the alluvial area of the confluence of the Dyje and Morava rivers in South Moravia. Administratively, the area belongs to the town of Valtice in the Czech Republic (coordinates $48^{\circ} 42^{\prime} 42.56^{\prime \prime} \mathrm{N}$, $16^{\circ} 47^{\prime} 54.47^{\prime \prime} \mathrm{E}$, the mean altitude being $97 \mathrm{~m}$ a.s.1.). The site has a mild eastern slope $\left(5^{\circ}\right)$. Predominant soil types are sandy loams and brown forest soils on loess accumulated during the Pleistocene (Hubálek et al., 2003). The climate in the region of the 
research site is relatively warm and dry with a mean annual temperature of about $9^{\circ} \mathrm{C}$ and average annual precipitation of about $500 \mathrm{~mm}$ (within a period of 50 years). Within the growing season (from May to October), the mean air temperature was $16.6^{\circ} \mathrm{C}$ and precipitation was $313 \mathrm{~mm}$ (Quitt, 1971; Klimo et al., 2008).

\section{Forest stand}

The dominant species of the main stand layer was European White Elm (Ulmus laevis Pall.) with the proportion of trees (calculated based on the number of trees of the tree species) amounting to $70 \%$. Several other species, namely European hornbeam (Carpinus betulus L.; 10\%), wild cherry (Prunus avium L.; 10\%), European ash (Fraxinus excelsior L.; 5\%), tree-of-heaven (Ailanthus altissima (Mill.) Swingle; 3\%) and smallleaved lime (Tilia cordata Mill.; 2\%) occur on the site. The total stocking density was 1 . The proportion of the tree species is reported for 1 ha. European hornbeam occurred strictly as undergrowth with the diameter at breast height (DBH) max. $3 \mathrm{~cm}$. The European hornbeam grows on the limit of the light compensation point. The other species have a DBH of $4-12 \mathrm{~cm}$.

The studied stand was a Pannonian oak-hornbeam forest according to Chytrý et al. (2001); the prevailing forest types were enriched oak-hornbeam woods and wet oak-hornbeam woods (Plíva, 1984; Viewegh et al., 2003). The woods are geobiocoenologically classified as Ulmi-fraxineta carpini inf. (Zlatník, 1976), which is equivalent to the mixed oak-elm-ash woods of large rivers, according to Devilliers and Devilliers-Terschuren (1996). The soil profile is composed of deep alluvial deposits on a fully hydrated gravel sandy subsoil of Pleistocene. Holocene deposits were classified as a semi-gley or brown alluvial soil (Šály, 1978).

\section{Experimental plot and selection of sample trees}

The experimental plot is an area of $1500 \mathrm{~m}^{2}(30$ $\mathrm{m} \times 50 \mathrm{~m})$; it was a mixed stand with the European White Elm as the dominant species with the proportion of trees $88 \%$ and several other species including European hornbeam (Carpinus betulus L.; 7\%), wild cherry (Prunus avium L.; 2\%), European ash (Fraxinus excelsior L.; 1\%), tree-of-heaven (Ailanthus altissima (Mill.) Swingle; 1\%) and small-leaved lime (Tilia cordata Mill.; 1\%) and contained 584 trees in total (approx. 3893 trees per ha), around 13 years old. The age of the trees was measured using the increment borer. Samples of wood were taken from the tree trunk at breast height. The tree annual rings were counted to determine the age of the trees. Wood samples were taken from seven elms and three wood samples were

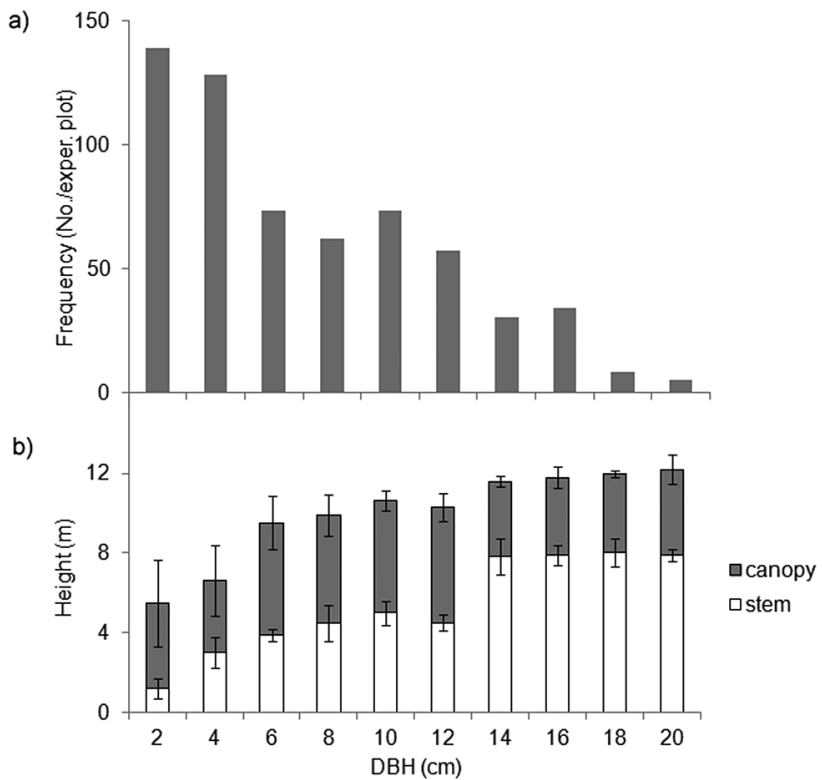

Fig. 1. a) The frequency distribution of diameter at breast height (DBH) classes. b) Mean stem and canopy height for the different $\mathrm{DBH}$ classes. The graph comprises all tree species. Each bar of the graph represents the tree height where the filled part represents the canopy length. The error bars $=$ standard deviation

taken from each of the remaining tree species. Trees growing on the experimental plot were planted via artificial regeneration with initial tree spacing of 1.8 $\mathrm{m} \times 0.8 \mathrm{~m}$ with one cleaning during the planting.

The DBH was measured for all trees (and all tree species) and used for classifying them at $2 \mathrm{~cm}$ increments for the purpose of scaling up the measurements to the stand area unit ( $1 \mathrm{ha}$ ). The stand structure including $\mathrm{DBH}$ and tree height was measured using the Field-Map technology (laser distance meter, compass, resistant tablet, monopod, and FieldMap Data Collector software) (IFER, Ltd., Jílové u Prahy, Czech Republic). The mean tree height in the entire stand was $12.1 \mathrm{~m}$ (Fig. 1), the mean height of the crown base (lowest living branch) was $6.3 \mathrm{~m}$ and the mean DBH was $10.5 \mathrm{~cm}$. The studied forest had a total basal area of $19.3 \mathrm{~m}^{2} \mathrm{ha}^{-1}$ with a basal area of 2.8 $\mathrm{m}^{2}$ per experimental plot. The basal area of the elm trees was $2.2 \mathrm{~m}^{2}$ per experimental plot.

Five European White Elm sample trees with a DBH of $6.1,8.6,12.1,14.1$ and $16.6 \mathrm{~cm}$ were chosen as sample trees for the study of leaf distribution. Based on stand basal area, another seven elm sample trees with a DBH of 5.9, 7.1, 8.6, 12.7, 14.0, 16.1 and $19.2 \mathrm{~cm}$ were selected for the root study (five of which were trees with the same or similar $\mathrm{DBH}$ as were those in the study of leaf distribution). The 'quantiles of total' statistical method was applied to select the sample trees (Čermák \& Kučera, 1990; Čermák \& Michálek, 1991; Čermák et al., 2004). Using this method, each sample tree represented the same fraction of the stand basal area. The number of sample 
trees was evaluated as adequate for the application of this statistical method since the stand was homogenous with low variability. The trees were felled and analysed in September 2010 (since this is the time of year when the development of living crown biomass is at its maximum) for the study of leaf distribution. The root measurement was carried out in May 2011. For the purposes of calculating the leaf area, foliage biomass, absorptive root area and the modelling of the thinning, the proportion of elms was considered $100 \%$ (including all tree species). This made it possible to simplify the computation of tree parameters while maintaining sufficient accuracy due to the low stocking density of other tree species.

\section{Determination of leaf distribution and foliage biomass}

The leaf distribution study was based on the 'cloud' technique (Čermák, 1989, 1998; Urban et al., 2009), which characterizes the aggregations of leaves on branches and their positions in the canopy. The horizontal and vertical projection of each individual leaf 'cloud', which was approximately ellipsoid, was displayed to scale on a square network $(25 \times$ 25 one-centimetre cells) in a spreadsheet (Čermák, $1989,1998)$. The tree height was represented on the vertical scale at $25 \mathrm{~cm}$ increments, while the crown radius was represented on the horizontal scale at $25 \mathrm{~cm}$ increments. Each leaf 'cloud' was characterized by the most accurate number of cells that filled the projected area. Leaf area (LA) of the harvested tree was derived from leaf dry weight using the measured data for leaf dry weight per area $\left(\mathrm{kg} \mathrm{m}^{-2}\right)$ for the same layers. Thus it means the quotient of leaf dry weight and leaf dry weight per area. Fresh and dry weight (after $48 \mathrm{~h}$ in a drying chamber at $80{ }^{\circ} \mathrm{C}$ ) was measured for samples of leaves as well as fresh weight foliage of each sample tree (with accuracy to one decimal place). The vertical leaf distribution of sample trees was generalized by allometric equations - so-called generalized sample trees were created. From the data on the leaf area it was possible to calculate the leaf area index of the tree level and then scale it up to forest stand. More details about the methodology of the data collection, calculations and derivations of leaf area are provided in Šrámek and Čermák (2012) who studied leaf distribution of European White Elm in this forest stand. The foliage biomass (FB) was calculated using the fresh weight foliage (including petioles) of each sample tree.

The leaf area and foliage biomass of the sample tree of individual $\mathrm{DBH}$ classes were converted to stand level (1 ha). The conversion was created using allometric equations and inventory data, i.e. derived values of the mean LA and mean FB of a sample tree, which were multiplied by the number of trees in the relevant DBH class. The sum of the data from all of these classes indicates the total leaf area and foliage biomass of the entire stand.

\section{Measurement of the absorptive root area (ARA)}

The ARA was measured by the modified earth impedance (MEI) method using the four-electrode system developed by Staněk (1997) and Aubrecht et al. (2006). This system has been field-tested by Čermák et al. (2006, 2013a, 2013b), Butler et al. (2010), Urban et al. (2011) and others.

If a simple electrical circuit is established between a tree and the soil, the current will only enter (or exit) the tree through the same porous surface area used in water and nutrient uptake. From the difference in conductivity of tree tissue and the soil, the soil-root exchange surface area was estimated with the use of the equation:

$$
S=\rho l \frac{I}{U}
$$

where $S$ is the total root absorption area (in square metres), $\rho$ is the resistivity of the water conducting tissue (in ohm metres), $l$ is the distance from the stem (in metres), $I$ is the current flowing through the wood stem, root system and soil to auxiliary metal electrodes from an external power supply (in amperes) and $U$ is the potential difference between the stem boundary and a potential electrode in the soil (in volts). Five electrodes were inserted into the stem of the tree and eight soil electrodes in a $60^{\circ}$ arc around the stem and connected to an alternating current generator. The soil electrodes were $10 \mathrm{~mm}$ in diameter and inserted $20 \mathrm{~cm}$ into the soil to ensure a sufficient conducting surface. An auxiliary potential electrode was inserted at the base of the trunk and another in the soil at a defined distance $l$ from the stem. The distance from the stem to both the current and potential soil electrodes was determined by the course of potential (voltage) characteristics. The amount of current flowing from the tree stem to the surrounding soil, via the root segment, decreases with increasing distance from the tree. This drop in voltage was mapped by progressively moving the soil potential electrode away from the stem in a radial direction. The point at which the drop in voltage plateaus is considered to be $l$, which corresponds to the mean distance of all the absorbing root segments of the tree. Resistivity of the water - conducting tissue $\left(\rho_{\text {wood }}\right)$ of the roots was calculated using the four-point Wenner method where $\rho_{\text {wood }}=2 \pi \mathrm{aR} \quad$ (Aubrecht et al., 2006). The four electrodes were inserted into 
the sapwood at equal distances. The electrical impedance, $R$, was measured with the electrodes 2,4 and $6 \mathrm{~cm}$ apart and the mean was calculated. Current was generated and the impedance measurements were made using a four-pole logometer (Fluke 1625 earth tester, Fluke Corporation, USA) operating under a voltage of $48 \mathrm{~V}$ and frequency of $94-128 \mathrm{~Hz}$. In the stand, seven trees were measured using the electrical impedance method. The target trees in the stand were chosen based on the 'quantiles of total' method (Čermák et al., 2004) so most of the range of tree sizes was covered and each tree represented approximately the same fraction of stand basal area. The measurement was repeated for four $60^{\circ}$ segments, each of which was multiplied by 1.5 and summed to estimate the entire tree root surface $\left(360^{\circ}\right)$.

The ARA values measured for a series of seven sample trees representing individual DBH classes were converted to stand level -1 ha (to compute the root area index - RAI). The ARA on the stand level was calculated by deriving the values of the ARA (using the allometric equation) and multiplying them by the number of trees in individual DBH classes and adding them up (Čermák et al., 2014).

The functional parameter RAI:LAI (i.e. the absorptive-to-desorptive ratio), which characterizes the two ecophysiologically relevant operating surfaces on the tree and stand level, was also computed.

\section{Determination of thinning treatment intensities}

To propose and classify the intensities of thinning measures, established silvicultural practices for forest management were followed. The proposed thinning intensities were based on common practice and current knowledge about growth, biology, production, cultivation and economics, e.g. as published by Poleno et al. (2007), Seidel et al. (2013) or Wilhelm and Rieger (2013). Trees in the experimental plot were classified using the Danish tree classification system (Peňáz, 1996, Table 1). This classification emphasizes the commercial importance of trees, and its simplicity and versatility make it convenient for evaluating the effectiveness of silvicultural measures according to three classes. The ranking in the classification is based on the economic importance of trees. For their simplicity and versatility, it is suitable for marking silviculture treatments in connection with positive selection. The trees which are marked (A) are the main trees with very high-quality stems and with proportionally big and symmetrical crowns. This is a category of future target trees. The group of trees marked (B) are called harmful side trees. These trees negatively influence the shape and growth of the main trees. The third group (C) are secondary useful trees positively
Table 1. Proposed simulated thinning intensities expressed as a percentage of all the trees removed from the individual diameter classes

\begin{tabular}{crccc}
\hline \multirow{2}{*}{ DBH $(\mathrm{cm})$} & \multicolumn{4}{c}{ Thinning intensity (\%) } \\
\cline { 2 - 5 } & low & medium & high & very high \\
\hline 2 & 52 & 54 & 55 & 55 \\
4 & 57 & 58 & 58 & 60 \\
6 & 54 & 57 & 65 & 100 \\
8 & 55 & 57 & 68 & 100 \\
10 & 63 & 65 & 83 & 100 \\
12 & 46 & 53 & 59 & 96 \\
14 & 66 & 69 & 69 & 69 \\
16 & 50 & 64 & 64 & 64 \\
18 & 20 & 80 & 80 & 80 \\
20 & 100 & 100 & 100 & 100 \\
\hline
\end{tabular}

affecting the formation and growth of the main trees. The last group (D) contains indifferent trees which cannot - in the time of the classifying - be reliably classified as (B) or (C). The main aim was to maintain and enhance elm vitality in the stand, while the aspect of production was evaluated only secondarily. Low-vitality trees and trees with forked stems were removed. Eventually, individuals that could be strong competitors to the promising individuals of Class A (Danish tree classification) were also removed. The thinning intensities were planned with respect to periodic thinning (every 5-7 years). Four thinning intensities were proposed based on the stand classification (low, medium, high and very high). In proposing optional intensities, emphasis a priori was placed on the method of target trees (very high and high intensity), which is commonly used with various modifications in France, Germany and Austria for cultivating valuable hardwood tree species. Less intensive measures were applied in the medium and low thinning options that represent the classic thinning from above, which corresponds to common practice in the Czech Republic. The thinning intensities were simulated for our experimental plot $\left(1500 \mathrm{~m}^{2}\right)$ and scaled up for the area of $1 \mathrm{ha}$. The experimental thinning intensities are characterized in Table 1. The number of trees before treatment was 3833 trees ha ${ }^{-1}$ (basal area $=19.27 \mathrm{~m}^{2} \mathrm{ha}^{-1}$, i.e. $100 \%$ ). The resultant number of trees at low, medium, high and very high thinning intensities after improvement cutting were 1827 trees $\mathrm{ha}^{-1}$ (basal area $=8.51 \mathrm{~m}^{2}$ ha $^{-1}$, i.e. $44 \%$ ), 1700 trees ha $^{-1}$ (basal area $=7.15 \mathrm{~m}^{2}$ ha $^{-1}$, i.e. $37 \%$ ), 1520 trees ha-1 (basal area $=5.90 \mathrm{~m}^{2} \mathrm{ha}^{-1}$, i.e. $31 \%$, with 200 target trees $\mathrm{ha}^{-1}$ ) and 993 trees ha $^{-1}$ (basal area $=2.71 \mathrm{~m}^{2}$ ha $^{-1}$, i.e. $14 \%$, with 100 target trees ha-1), respectively.

The target trees are a number of well-spaced acceptable trees per hectare that will, under normal circumstances, produce an optimum or the best semifree-growing crop. They are the trees with the best size, shape, vitality and quality at which silviculture treatments are aimed. 
The thinning intensity was simulated using MS Excel and data derived from the spreadsheet used in the leaf distribution study; part of the spreadsheet is a logbook containing measurement data.

\section{Data analysis}

Regressions (based on coefficients of the double-Gauss function) were used to generalize the leaf distribution of individual trees and the data was scaled up for whole stands by relating the coefficients to forest inventory data. The coefficients were derived separately for each DBH class, and leaf dry weight was estimated for canopy layers as a function of height at $25 \mathrm{~cm}$ resolution (see also Šrámek \& Čermák, 2012).

The parameter DBH was used as an independent variable in linear and non-linear models (i.e. allometric equations) that were created to predict the leaf area, foliage biomass and absorptive root area through the DBH range. Plotted data suggested that they followed either linear, exponential, power law or Gompertz functions, which were fitted to the data and compared. The other possible functional forms were also tested (Paine et al., 2012), but they had much worse fits to the data and were not considered further in this study.

The formulae used for the three models were:

a) linear: $y=a x+b$

b) exponential: $y=e^{(a+b x)}$

c) power law: $y=a x^{b}$

d) Gompertz: $y=a e^{-b e^{(-\alpha)}}$

where $y$ is the response variable (LA, FB, ARA ), $x$ is the DBH and $a, b$ and $c$ are the model coefficients. Generalized non-linear models (GNLMs) were used for creating the models in this study.

The Root Mean Squared Error (RMSE), second-order Akaike Information Criterion (AICc) (Burnham \& Anderson, 2002) and likelihood-ratio based on pseudo- $\mathrm{R}^{2}$ (Magee, 1990) with Nagelkerke's adjustment (pseudo- $\mathrm{R}_{\text {adj }}^{2}$ ) (Nagelkerke, 1991) were calculated for each model. The differences between AICc

a) Sample trees

$\mathrm{DBH}=6.1 \mathrm{~cm}$

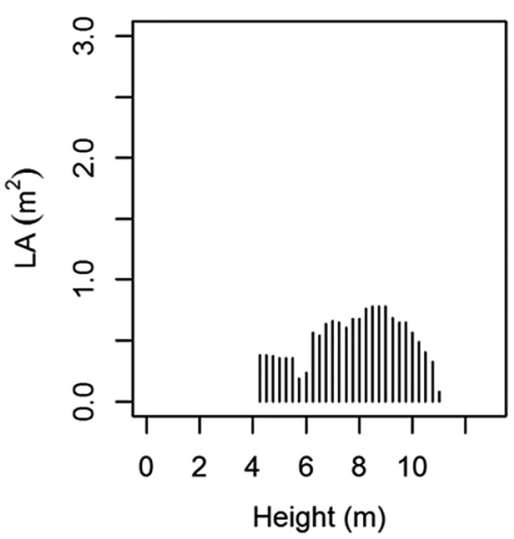

b) Generalized trees

$\mathrm{DBH}=6.1 \mathrm{~cm}$

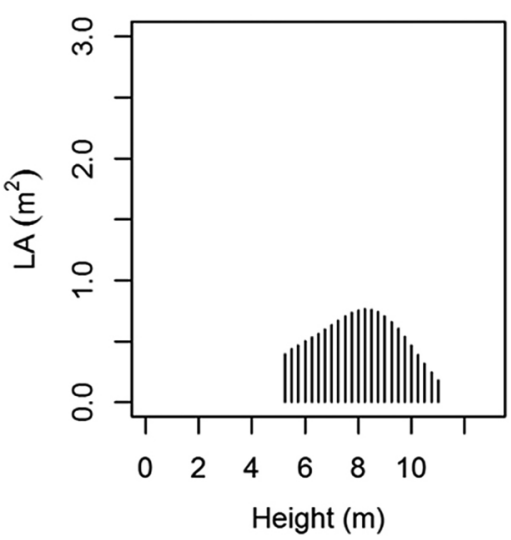

$\mathrm{DBH}=12.1 \mathrm{~cm}$

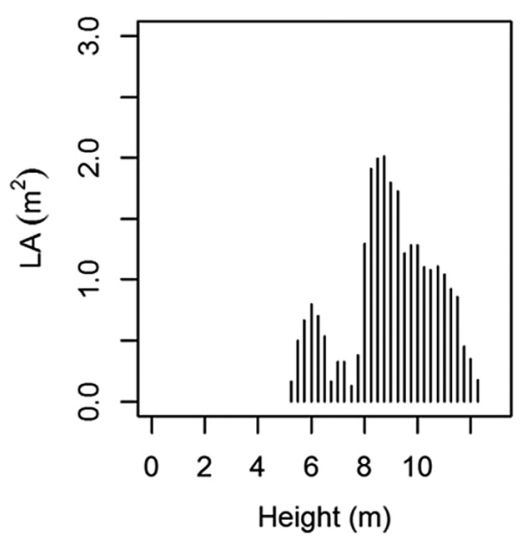

$\mathrm{DBH}=12.1 \mathrm{~cm}$

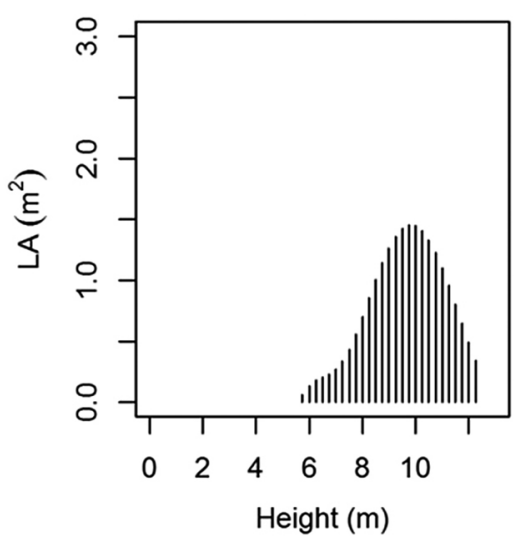

$\mathrm{DBH}=16.6 \mathrm{~cm}$

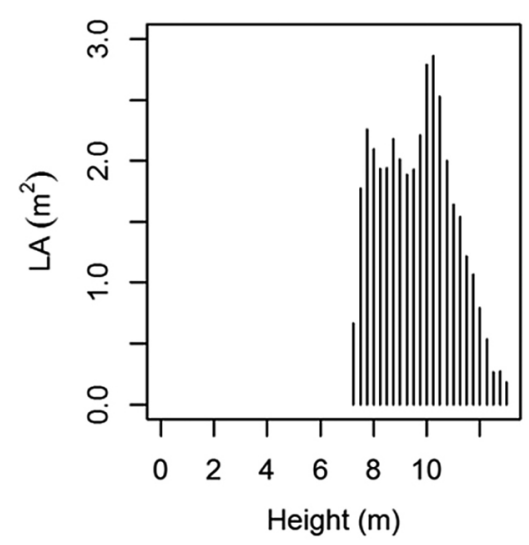

$\mathrm{DBH}=16.6 \mathrm{~cm}$

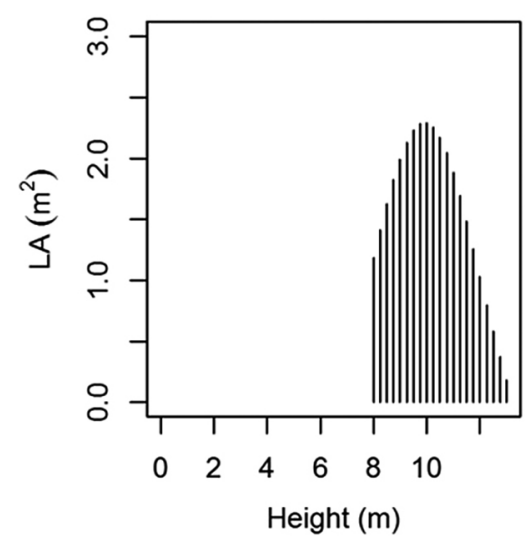

Fig. 2. a) Vertical profiles of leaf area for three of the five Ulmus laevis sample trees (small, medium and large trees). b) Vertical profiles of leaf area for three generalized Ulmus laevis model trees. Leaf area is represented by the size of each vertical bar. LA - leaf area, DBH - diameter at breast height 

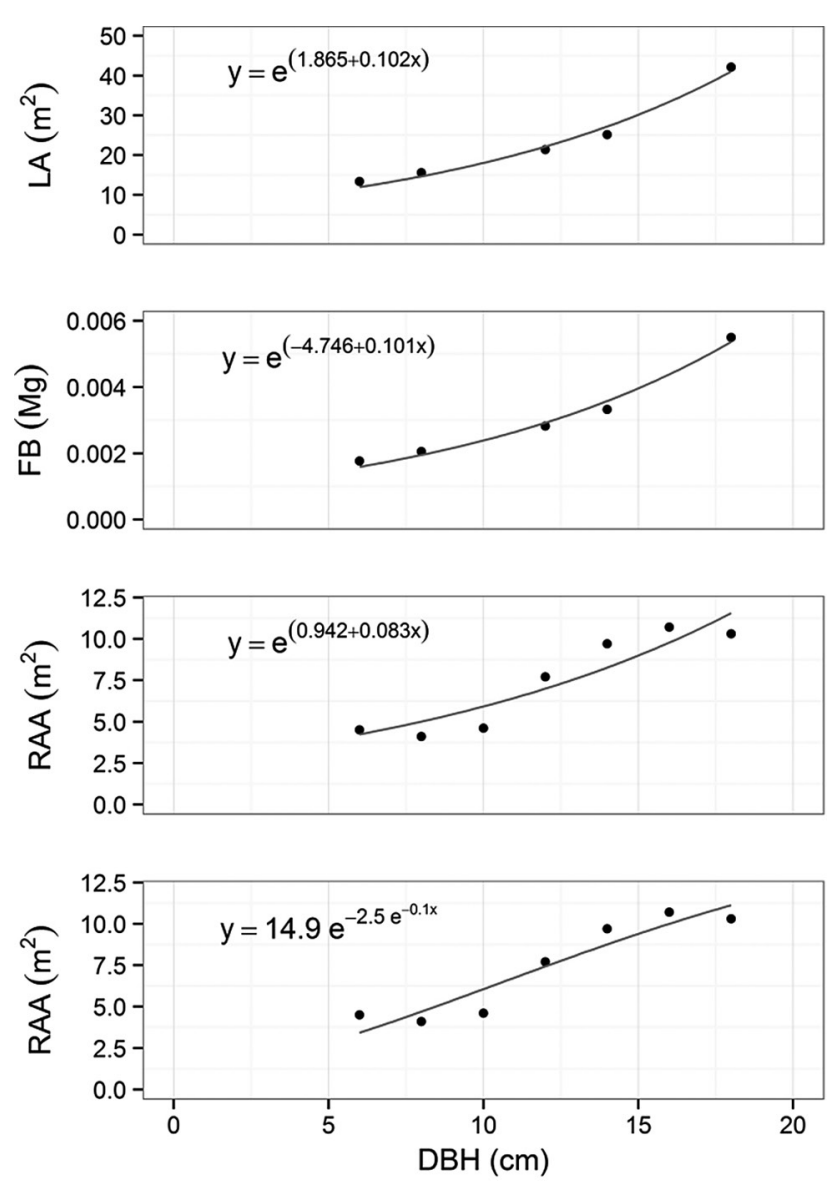

Fig. 3. Allometric relationship of above- and below-ground tree parameters to DBH and estimated parameters of the elm sample trees (dots). The proposed allometric equations for the leaf area (LA), foliage biomass (FB) and absorptive root area (ARA) - for both exponential and Gompertz equations. DBH - diameter at breast height

values $(\triangle \mathrm{AICc})$ for linear, exponential and power law models were also calculated and those with lower AICc values were selected. Model fitting and testing was conducted according to Matula et al. (2015).

All analyses were carried out in the $\mathrm{R}$ environment (R Core Team 2012). Model coefficients and allometric equations for leaf area, foliage biomass and absorptive root are contained in Fig. 3.

\section{Results}

\section{Individual tree level}

Vertical leaf distribution of the three selected sample trees (small, medium and large) and their generalized model trees are shown in Fig. 2. The leaf distribution had the highest values at $8.5 \mathrm{~m}(71 \%$ of the tree height for both small and large trees) in trees with a lower DBH $(\leq 10 \mathrm{~cm})$ and $10.5 \mathrm{~m}(87 \%$ of the tree height) in trees with a higher DBH (range 11 to $20 \mathrm{~cm}$ ). The vertical leaf distribution was bimodal in sample trees with smaller dimensions and was unimodal in sample trees with larger dimensions. However, it seemed to be unimodal in the generalized sample trees for all DBH classes and suitable for scaling up tree data to the stand level. The mean leaf area (generalized tree) was $24.7 \mathrm{~m}^{2}$, which corresponds to the mean number of leaves 6480 per generalized tree. The mean leaf area was $38.1 \pm 2.8 \mathrm{~cm}^{2}$ and specific leaf area was $19.3 \mathrm{~m}^{2} \mathrm{~kg}^{-1}$.

The LAI of individual model trees depended on the area of the crown projection and leaf area (the range of LAI was 1.7-5.7). Regarding the DBH classes, the highest LAI values were found in trees with a DBH of 6.1 and $16.6 \mathrm{~cm}$.

The foliage biomass of the smallest trees with a DBH of $6.1 \mathrm{~cm}$ was approximately $1.7 \mathrm{~kg} \mathrm{ha}^{-1}$. The largest trees with a DBH of $16.6 \mathrm{~cm}$ had approximately $5 \mathrm{~kg} \mathrm{ha}^{-1}$ of the FB. The FB per individual tree was exponentially related to the tree $\mathrm{DBH}$. A linear relationship between the DBH and ARA was found. This value increased with $\mathrm{DBH}$ from $4.1 \mathrm{~m}^{2}$ to $10.7 \mathrm{~m}^{2}$ in the suppressed and the dominant tree, respectively.

\section{Stand level}

The total leaf area per forest stand (1 ha) reached $65000 \mathrm{~m}^{2}$, which corresponds to a stand LAI of 6.5 (4.0 without the undergrowth - without trees with $\mathrm{DBH} \leq 2 \mathrm{~cm}$ and a without herb layer). The number of leaves per ha was approximately $10.5 \times 10^{6}$. The vertical LAI profile for the entire stand showed the highest values in the middle layer of the canopy $(9.5 \mathrm{~m})$. The total foliage biomass reached $8.2 \mathrm{Mg} \mathrm{ha}^{-1}$. The below-ground tree parameter (i.e. RAI) per forest stand was 1.7 (i.e. $30 \%$ of the leaf area index with undergrowth). Considering the comparison of two ecophysiologically relevant operating surfaces (absorptive/desorptive) of the stand, the value of RAI was $73 \%$ lower than that of LAI. The total RAI:LAI was 0.26 .

\section{Allometric equations of the tree parameters}

Exponential models (allometric equations) were created to predict the leaf area, foliage biomass and absorptive root area through the DBH classes (Fig. 3). The AICc value for the leaf area model was 22.99 with pseudo- $\mathrm{R}^{2}$ adj value $=0.95$. The foliage biomass exponential model reached the AICc value $=$ -66.9 and pseudo- $\mathrm{R}_{\text {adj }}$ value $=0.98$. An exponential model (AICc $=26.44$, pseudo- $\mathrm{R}_{\text {adj }}^{2}$ value $=0.86$ ) was also created for the absorptive root area, although the Gompertz model (Fig. 3) seems to be suitable as well (AICc $=26.49$, pseudo- $\mathrm{R}_{\text {adj }}^{2}$ value $\left.=0.97\right)$. 


\section{Tree parameters after thinning modelling}

The results of the modelling of the individual ecophysiological parameters are presented in Table 2 . The modelled LAI exhibited a descending trend with increasing thinning intensity, and its value among the proposed (low, medium, high and very high) thinning intensities decreased by $55 \%\left(10.75 \mathrm{~m}^{2} \mathrm{ha}^{-1}\right.$ of the basal area removed), $61 \%\left(12.13 \mathrm{~m}^{2} \mathrm{ha}^{-1}\right.$ of the basal area removed), $65 \%\left(13.37 \mathrm{~m}^{2} \mathrm{ha}^{-1}\right.$ of the basal area removed) and $87 \%\left(16.56 \mathrm{~m}^{2} \mathrm{ha}^{-1}\right.$ of the basal area removed), respectively. The development trend of other above- and below-ground tree parameters was very similar with the exception of the trend of the RAI:LAI ratio (Fig. 4). This parameter is, to a great extent, dependent on the total amount of leaf area and absorptive root area. The RAI:LAI ratio compares two relevant functional production surfaces and exhibits a trend where (compared with the initial condition) the values decrease (by $2-6 \%$ ) as
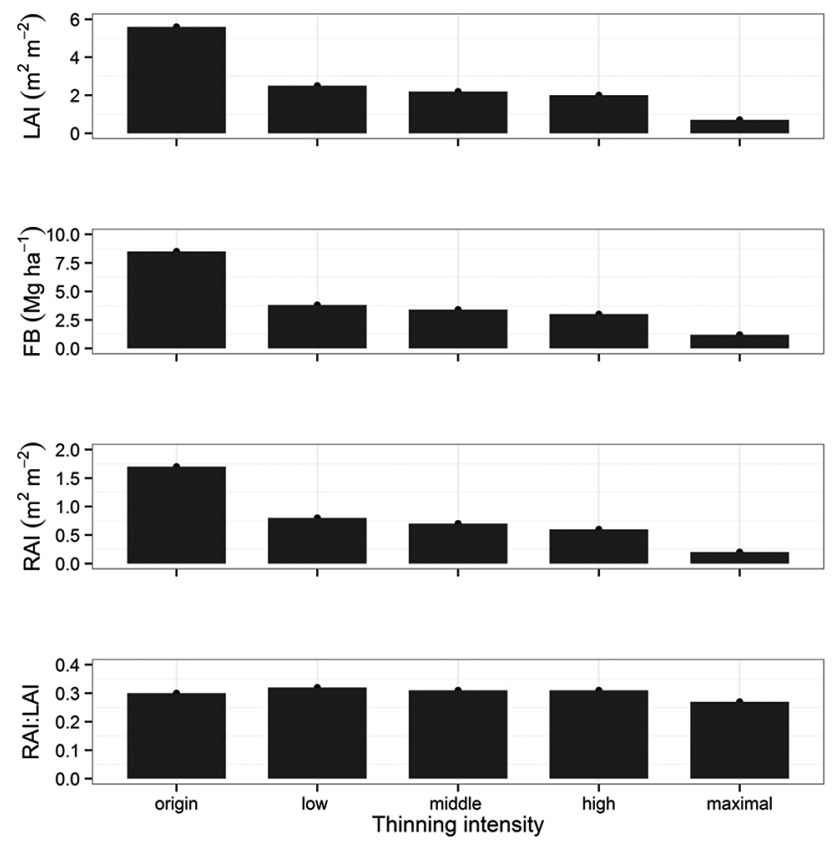

Fig. 4. Modelling of the development of the tree parameters at the given thinning intensities. LAI - leaf area index; FB - foliage biomass; RAI - absorptive root area index; RAI:LAI -absorptive root area index to leaf area index ratio the thinning intensity increases only up to the medium intensity of the thinning. With maximal thinning intensity, the value of RAI:LAI decreased by $11 \%$ compared with the initial condition.

\section{Discussion}

Nowadays, more and more information not only on the above- but also the below-ground parts of trees is being obtained, particularly for common tree species. This knowledge is necessary for description of the structure and function of trees as well as forest stands and forest ecosystems. Much knowledge of elms as an endangered tree species remains to be acquired. Since available literature lacks sufficient knowledge about this topic, the aims of this study are to fill these gaps.

\section{Individual tree level}

The knowledge about the vertical leaf distribution of native tree species growing together with elms is quite poor. Therefore, some non-native tree species growing in association with elms were also discussed. The highest vertical distribution of leaf area measured in this study is similar to data on invasive tree species Prunus serotina (Ehrh.) for the same DBH classes presented by Urban et al. (2009). This species, which creates undergrowth in pine stands, reaches its highest vertical leaf distribution values at $85.7 \%$ of the height of large trees $(\mathrm{DBH}=$ $19.7 \mathrm{~cm})$ and at $80 \%$ of the height of smaller trees $(\mathrm{DBH}=3.2 \mathrm{~cm})$. This is an interesting finding due to the fact that Prunus serotina is undergrowth and elms are tree species of the main layer. This may be due to different architecture crown which means interspecies differences. Čermák et al. (2008) found the highest vertical leaf area distribution values in Quercus cerris L. and Quercus pubescens Willd., at $61 \%$ of the tree height and $46 \%$ of the tree height, respectively; Olea europea L. 'Coratina' reached its maximum at $30-60 \%$ of the tree height (Čermák et al., 2007, 2011). These values are slightly lower than those of elm. The differences are likely caused by the differing architecture of the crowns across species. In general, the crown shape of undergrowth medium-sized

Table 2. Results of the modelling of tree parameters at the four simulated thinning intensities. (T. I. (\%) = thinning intensity expressed as a percentage of the number of removed individuals; Trees $\mathrm{ha}^{-1}=$ number of trees remaining on the plot)

\begin{tabular}{|c|c|c|c|c|c|c|c|}
\hline Thinning intensity & T. I. (\%) & Trees ha $^{-1}$ (No.) & LAI $\left(\mathrm{m}^{2} \mathrm{~m}^{-2}\right)$ & FB $\left(\mathrm{Mg} \mathrm{ha}^{-1}\right)$ & ARA $\left(\mathrm{m}^{2}\right)$ & RAI $\left(m^{2} m^{-2}\right)$ & RAI:LAI $\left(\mathrm{m}^{2} \mathrm{~m}^{-2}\right)$ \\
\hline Origin & - & 3833 & 5.6 & 8.5 & 16998 & 1.7 & 0.30 \\
\hline Low & 55.3 & 1827 & 2.5 & 3.8 & 7900 & 0.8 & 0.32 \\
\hline Medium & 58.4 & 1700 & 2.2 & 3.4 & 6850 & 0.7 & 0.31 \\
\hline High & 62.8 & 1520 & 2.0 & 3.0 & 5901 & 0.6 & 0.31 \\
\hline Very high & 75.7 & 993 & 0.7 & 1.2 & 2018 & 0.2 & 0.27 \\
\hline
\end{tabular}


trees is that of an umbrella due to the need to capture diffusion light, whereas trees of the main level are in the shape of a narrow crown with a higher relative length of the crown. The mean leaf measures are similar to the values presented by other authors (Vyskot, 1976; Vašíček, 1980; Urban et al., 2009) for the species Quercus, Fraxinus and Tilia. More precisely, there are some systematic deviations: $\pm 10 \%$ for dry leaf mass, $\pm 30 \%$ for leaf area; the number of leaves per tree is substantially different, as this is greatly affected by the ages and dimensions of trees. This can be stated due the fact that similar habitats were compared. The values for foliage biomass were similar to those reported for Wych elm (Ulmus glabra Huds.) in an uneven-aged mixed ash-elm stand in Italy (Alberti et al., 2005). This fact suggests that the created allometric equation for foliage biomass can be used generally for the tree species of the same genus, although these species have different environmental requirements. The ash trees (Fraxinus excelsior L.) have lower foliage biomass in the same DBH classes in the study of Alberti et al. (2005) than for elm trees in the study area, despite the fact that the study area has lower annual rainfall than the research locality in Italy. Ash was a dominant tree species in the study of Alberti et al. (2005). Lower ash foliage biomass could be caused by interspecific competition, a lower value of specific leaf area (dominance of sunlit leaves) and differences in crown and leaf architecture. The shade-tolerant character of elms seems to be a competitive advantage for production of foliage biomass.

The absorptive root area (ARA) data has, according to literature, been limited due to the absence of instrumentation for surveying the ARA; this equipment is now available, providing valuable information about the root system. This method of measuring the ARA has been used, for example, in surveying the health condition of an oak alley alongside a road (Čermák et al., 2013b). Due to the lack of relevant information on the absorptive root area, this parameters is also compared with data from conifers. Butler et al. (2010) reported that the ARA for Sitka spruce with a stand density comparable to that of the elm stand in this study was approximately $50 \%$ lower. These differences are due to differences in species and, in particular, site soil conditions. At the time of planting the Sitka spruce stand, the soil was prepared. The trees were planted on parallel-mounded ridges (also known as ribbons) separated by drainage trenches. The trees in stands were sustained by a shallow peat ( $\sim 30 \mathrm{~cm}$ deep in the furrows). Therefore the root system of spruce was endowed with good soil conditions and absorption root area was developed in adequate proportions to the site. ARA measuring on the tree level gives interesting data and can provide important information on the health of a tree, for example about the uptake of water on the site and approximate information about the groundwater level. The practical implication of ARA measuring can be for example for the assessment of hypoxia in the soil (Čermák et al., 2011, 2014). This kind of damage often occurs in floodplain forests in the vicinity of this study area. Generally, this damage is reflected in a reduction of ARA in the measured root section of a tree. Soil hypoxia did not appear in this study.

\section{Stand level}

The vertical profile of LAI for the portion of the stand with the highest values in the middle layer of the crown was similar to that presented by Vose et al. (1995) for an oak stand (Quercus alba L., Q. rubra L., Q. prinus L.) with a mean DBH of $15.3 \mathrm{~cm}$; Čermák et al. (2008) obtained similar results in an adult stand of Quercus cerris; for younger Quercus pubescens, the highest LAI value was observed below the middle crown layer. The LAI value of 5.0 was reported by Čermák et al. $(1998,2011)$ in the stand under the conditions of a two-stage mixed deciduous floodplain forest (Quercus robur L., Fraxinus excelsior, F. angustifolia Vahl. and Tilia cordata Mill.) planted in 1880. The stand LAI of elm forests is about $20 \%$ smaller. This different value is mainly due to the different age structure of the compared forest stands. Alberti et al. (2005) presented an LAI of 3.7 for uneven-aged mixed ash-elm forests (with DBH range $5-30 \mathrm{~cm}$ ), which was about $8 \%$ lower than that for the observed elm forest stand. The LAI of 4.3 for a pre-dominantly oak stand was presented by Kull et al. (1999), and that value was about $7 \%$ higher than that observed in the elm forest stand. The relatively high value of the total LAI (including undergrowth) in this study is caused by the high number of the very small trees $(\mathrm{DBH}=2 \mathrm{~cm})$ in the undergrowth. It can be expected that most of these trees die within a few years due to competition.

The significance of the RAI:LAI ratio was previously noted by Čermák and Prax (2001), but procedures for the empirical measurement of ARA were not developed until later (Aubrecht et al., 2006). The estimation of RAI (i.e. absorptive RAI) permits a comparison with LAI (or preferably, sunlit LAI) and therefore an evaluation of the RAI:LAI ratio, which can be understood as a structural tree balance of nutrient uptake and release. This is a very important parameter (which is much more often applied for example in agriculture) that often indicates the probability of tree survival under unfavourable environmental conditions (Sperry et al., 1998; Čermák et al., 2011, 2014). The RAI:LAI ratio in forestry is of practical importance for the ecophysiologically relevant comparison of the absorptive and desorptive operating 
surfaces. The measurement of these parameters is important for the balanced management of forest ecosystems, as noted by Čermák et al. (2013a) and may be applicable for assessing the production potential or health condition at the tree or stand level. The relatively constant development of the RAI:LAI ratio seems to be an equilibrium of structural tree balance through the proposed thinning intensity in the study area. Knowledge of the RAI:LAI ratio may contribute, for example, to a greater understanding of elm diseases, providing there is a connection with the generally known fact that a balanced state of health increases resistance to the attack of a vector of disease. This index is expected to vary among stands growing on different sites (Čermák et al., 2011, 2014).

The opening of a forest stand by removing trees during thinning leads to enhancing root growth at tree level as a results of more space. This effect was observed mainly in coniferous trees (Ruel et al., 2003; Vincent et al., 2009) and might be also applicable for deciduous trees.

In contrast, root systems developed for a certain survival limit (originally adjusted to a sufficient soil water supply in floodplain forests, where the level of underground water suddenly decreases) can appear to be very drought-sensitive. Therefore the RAI:LAI ratio may show an approaching tree survival limit (based on the rule where the lower the value, the higher the probability of nearing the survival limit). As had been expected at the beginning of this study, the value of RAI:LAI was different to the results reported by Butler et al. (2010) in the Sitka spruce managed forest planted 45 years ago. The RAI:LAI ratio was $47 \%$ higher than that in the Sitka spruce forest. This ratio is strongly dependent on species, tree density and soil, because it represents above and below- ground parts of trees which are affected by the surrounding site.

\section{Allometric equations}

The diameter at breast height explains most of the variability of the dependent variables (i.e. the total above-ground biomass or the stem, branch and/or foliage biomass individually). The harvest method is undoubtedly the most accurate method for estimating above-ground biomass volume (Parresol et al., 1999; Clark et al., 2001). Nevertheless, allometric equations are commonly used for forest inventories and ecology studies. In particular, estimation of above-ground biomass is an essential aspect of studies of $\mathrm{C}$ stocks and $\mathrm{C}$ sequestration on the global C balance (Alberti et al., 2005). These estimates are typically based on allometric regression equations developed using dimensional analysis techniques (Jenkins et al., 2003). Species-specific allometric equations (exponential equations) were used because trees of different species can differ in architecture, leaf dry mass per area and in specific leaf area. However when the foliage biomass of the European White Elms was compared with the results of the Whych elm reported by Alberti et al. (2005), it was quite similar. These results indicate that the created allometric equation for foliage biomass can be used for the tree species of the same genus generally. Nonlinear models are flexible enough to account for varying biomass estimation (Pontailler et al., 1997; Schroeder et al., 1997; Pain et al., 2012). The absorptive root area was a better fitted exponential model, although the Gompertz model also seems to be suitable. Using the Gompertz model might be more appropriate in the case of extrapolation of data to higher DBH classes because it is a sigmoid function, where growth is slowest at the start and end of the interval (for example DBH classes). This effect was demonstrated during the experimental data extrapolation up to higher DBH. The developed equations are useful for both practical forestry issues and scientific purposes. Although a relatively small number of sample trees was used for allometric equations, the accuracy of results is sufficient due to the lack of information on this topic for elm species.

\section{Tree parameters after thinning modelling}

Reducing the number of trees in the stand by thinning naturally causes a decrease in LAI as well as leaf area, foliage biomass and the absorbing root area index of the stand. The trend of the decline of the observed parameters seems to be similar for all the parameters per stand. On the other hand, these parameters are increasing due to the obtained space thus gaining a competitive advantage at tree level. The increase in sunlit leaf area should lead to potentially higher photosynthesis, increase in biomass and enhanced stand vitality and vigour. Increasing photosynthesis, by increasing leaf area and sunlit leaf area at tree level, will also cause evapotranspiration to increase (Bodin \& Franklin, 2012). After thinning, the increased photosynthetic activity of the leaf area must be supported by increased water supply from the soil through the ARA (Shipley \& Meziane, 2002). Therefore, it can be assumed that there will be a slight increase in the ARA on the tree level, although the total ARA of the forest stand after thinning has decreased.

Development of the RAI:LAI ratio slightly increased after (thinning) modelling and seemed to be constant until the high intensity of thinning when it started to decrease. This can be an economically unsuitable RAI:LAI ratio where the trees do not fully 
utilize the production space and/or biomass growth is relatively large compared to the development of the root system. On the other hand, intensive thinning could be utilized in the support of certain ecosystem functions in the protection of nature or the vitality of elms in forest stands. Therefore, there seems to be a suitable medium and high thinning intensity due to vitality of the elm forest stand. Maximal intensity, from the forestry and commercial point of view, is not suitable due to the bigger potential formation of thick branches and thus lower quality of the stems of trees. On the other hand, a low intensity of thinning can cause an inappropriately high slenderness ratio (height/DBH ratio) and subsequently low stability and vitality of the stand. Thinning modelling variants might facilitate the control of further development of thinned stands. Management of stand leaf area and stand structure could promote efficient utilization of irradiation, which supports a higher biomass production and improves the vitality of forest stands.

\section{Conclusion}

This study introduced a description of a young elm forest stand, including allometric equations for leaf area, foliage biomass, absorptive root area and the changes in these tree parameters after the modelling of thinning. Process-based models commonly operate on a unit area level and the operator needs to know the stand biometry to either downscale empirically measured input data or to upscale the model outputs. Simulation of the change in these parameters after thinning outlines the state of the stand after cutting. Knowledge of these changes is relevant for future management of similar forest stands. Acquiring new quantitative knowledge about the structure and biometric parameters of each tree and also forest stand is an essential requirement for understanding (i.e. finding out how to conserve) and planning the management of this valuable and endangered tree species. It may help to better understand their ecological requirements. The LAI of a young elm stand was 5.6, the absorptive root area index was 1.7 and the total biomass of foliage per stand was $8.5 \mathrm{Mg} \mathrm{ha}^{-}$ ${ }^{1}$. Simulation of LAI, FB and RAI of four thinning intensities was negatively correlated with the number of trees in the plot, where the decrease ranged from $12-47 \%$ of the pre-treatment value. The RAI:LAI ratio (which can be understood as a structural tree balance) shows a consistent trend (increase of 3\%) towards the high intensity of thinning where the maximal intensity decreases. A significant decline in this value might mean the achievement of a certain survival limit of the trees. This may have important implications for health assessment. Nonlinear models (species-specific allometric equations) were developed to predict the leaf area, foliage biomass and absorptive root area through the DBH classes. These equations are necessary background information for up-scaling of physiological data measured on a limited tree level. The presented study provides a basis for better understanding elm issues as well as for its utilization in ecosystem services (providing allometric equations) for forest stands in which endangered elms are a dominant or subdominant species.

\section{Acknowledgements}

The paper was prepared within the NAZVA BIOLUH (no. QI92A031) and NAZV (no. QI102A085) grant projects entitled "Optimization of silvicultural measures to increase biodiversity in commercial forests", organized by the Ministry of Agriculture of the Czech Republic.

\section{References}

Alberti G, Candido P, Peressotti A, Turco S, Piussi P \& Zerbi G (2005) Aboveground biomass relationships for mixed ash (Fraxinus excelsior $\mathrm{L}$. and Ulmus glabra Hudson) stands in Eastern Prealps of Friuli Venezia Giulia (Italy). Annals of Forest Science Sciences 62: 831-836. doi:http://dx.doi. org/10.1051/forest:2005089.

Aubrecht L, Staněk Z \& Koller J (2006) Electrical measurement of the absorption surfaces of tree roots by the earth impedance method: 1 . Theory. Tree Physiology 26: 1105-1112. doi:http://treephys.oxfordjournals.org/content/26/9/1113.full. pdf.

Baldocchi D, Hutchinson B, Matt D \& McMillen R (1986) Seasonal variation in the statistics of photosynthetically active radiation penetration in an oak-hickory forest. Agricultural and Forest Meteorology 36: 343-361. doi:10.1016/01681923(86)90013-4.

Barbosa P \& Wagner MR (1989) Introduction to forest and shade tree insects. San Diego, Academic Press, USA.

Bodin P \& Franklin O (2012) Efficient modeling of sun/shade canopy radiation dynamics explicitly accounting for scattering. Geoscientific Model Development 5: 535-541. doi:10.5194/gmd-5535-2012.

Brasier CM (1991) Ophiostoma novo-ulmi sp. nov., causative agent of the current Duch elm disease pandemics. Mycopathologia 115: 151-161. doi:10.1007/BF00462219.

Burnham KP \& Anderson DR (2002) Model selection and multi-model inference: a practical information-theoretic approach. 2nd ed. Springer-Verlag, New York, Berlin, Heidelberg, Germany. 
Butler AJ, Barbier N, Čermák J, Koller J, Thornily C, McEvoy C, Nicoll B, Perks MP, Grace J \& Meir $P$ (2010) Estimates and relationships between aboveground and belowground resource exchange surface areas in a Sitka spruce managed forest. Tree Physiology 30: 705-714. doi:10.1093/ treephys/tpq022.

Čermák J (1989) Solar equivalent leaf area: an efficient biometrical parameter of individual leaves, trees and stands. Tree Physiology 5: 269-289. doi:10.1093/treephys/5.3.269.

Čermák J \& Kučera J (1990) Scaling up transpiration data between trees, stands and watersheds. Silva Carelica 15: 101-120.

Čermák J \& Michálek J (1991) Selection of sample trees in forest stands using the quantils of total. Lesnictví 37: 49-60.

Čermák J (1998) Leaf distribution in large trees and stands of the floodplain forest in southern Moravia. Tree Physiology 18: 727-737. doi:http:// treephys.oxfordjournals.org/content/18/11/727. full.pdf.

Čermák J \& Prax A (2001) Water balance of a Southern Moravian floodplain forest under natural and modified soil water regimes and its ecological consequences. Annals of Forest Science 58: 1529. doi:10.1051/forest:2001100.

Čermák J, Kučera J \& Nadezhdina N (2004) Sap flow measurements with some thermodynamic methods, flow integration within trees and scaling up from sample trees to entire forest stands. Trees 18: 529-546. doi:10.1007/s00468-004-0339-6.

Čermák J, Ulrich R, Staněk Z, Koller J \& Aubrecht L (2006) Electrical measurement of tree root absorbing surfaces by the earth impedance method: 2. Verification based on allometric relationships and root severing experiments. Tree Physiology 26: 1113-1121. doi:10.1093/treephys/26.9.1113.

Čermák J, Gašpárek J, De Lorenzi F \& Jones HG (2007) Stand biometry and leaf area distribution in an old olive grove at Andria, southern Italy. Annals of Forest Science 64: 491-501. doi:https:// hal.archives-ouvertes.fr/hal-00884101/document. Or https://hal.archives-ouvertes.fr/hal00884101.

Čermák J, Tognetti R, Nadezhdina N \& Raschi A (2008) Stand structure and foliage distribution in Quercus pubescens and Quercus cerris forests in Tuscany (central Italy). Forest Ecology and Management 255: 1810-1819. doi:10.1016/j.foreco.2007.12.003.

Čermák J \& Nadezhdina N (2011) Field studies of whole-tree leaf and root distribution and water relations in several European forests. Chapter 4: Forest Management and the Water Cycle (ed. by M Bredemeier, S Cohen, DL Godbold, E Lode, V
Pichler \& P Schleppi) Springer Netherlands, pp. 65-88. doi:10.1007/978-90-481-9834-4.

Čermák J, Cudlín P, Gebauer R, Børja I, Martinková M, Stanĕk Z, Koller J, Neruda J \& Nadezhdina N (2013a) Estimating the absorptive root area in Norway spruce by using the common direct and indirect earth impedance methods. Plant and Soil 372: 401-415. doi:10.1007/s11104-013-1740-y.

Čermák J, Simon J, Káňová H \& Tichá S (2013b) Absorptive root areas of large pedunculate oak trees differing in health status along a road in South Bohemia, Czech Republic. Urban Forestry \& Urban Greening 12: 238-245. doi:10.1016/j. ufug.2013.02.003.

Čermák J, Nadezhdina N, Nadezhdin V, Staněk Z, Koller J, Trcala M \& Kantor P (2014a) Absorptive root area and stem resistivity in whole trees of contrasting structure and size-improvement of methods. Plant and Soil 383: 257-273. doi:10.1007/s11104-014-2126-5.

Čermák J, Nadezhdina N, Trcala M \& Simon J (2014b) Open field-applicable instrumental methods for structural and functional assessment of whole trees and stands. iForest-Biogeosciences and Forestry 8: 226-278. doi:10.3832/ifor1116-008.

Clark DA, Brown S, Kicklighter DW, Chambers JQ, Thomlinson JR \& Ni J (2001) Measuring net primary production in forests: Concepts and field methods. Ecological Applications 11: 356-370. doi:10.1890/1051-0761(2001)011 [0356:MNPPIF]2.0.CO;2.

Devilliers P \& Devilliers-Terschuren J (1996) A classification of Palaearctic habitats. Nature and environment 78. Council of Europe Publishing, Strasbourg.

Hemery GE, Clark JR, Aldinger E, Claessens H, Malvolti ME, O'connor E, Raftoyannis Y, Savill PS \& Brus R (2010) Growing scattered broadleaved tree species in Europe in a changing climate: a review of risks and opportunities. Forestry 83: 65-81. doi:10.1093/forestry/cpp034.

Hoffmann CW \& Usoltsev VA (2002) Tree-crown biomass estimation in forest species of the Ural and of Kazakhstan. Forest Ecology and Management 158: 59-69. doi:10.1016/S0378-1127(00)006691.

Hubálek Z, Haluzka J \& Juřicová Z (2003) Longitudinal surveillance of the tick Ixodes ricinus for borreliae. Medical and Veterinary Entomology 17: 46-51. doi:10.1046/j.1365-2915.2003.00408.x.

Chytrý M, Kučera T, Kočí M, Grulich V \& Lustyk P (2001) Katalog biotopů České republiky. Agentura ochrany př́rody a krajiny ČR, Praha.

Jassim HK, Foster HA \& Fairhurst CP (1990) Biological control of Dutch elm disease: Larvicidal activity of Trichoderma harzianum, Trichoderma polysporum and Scytalidium lignicola in Scolytus scoly- 
tus and Scolytus multistriatus reared in artificial culture. Annals of Applied Biology 117: 187-196. doi:10.1111/j.1744-7348.1990.tb04206.x.

Jenkins JC, Chojnacky DC, Heath LS \& Birdsey RA (2003) National-scale biomass estimators for United States tree species. Forest Science 49: $12-35$.

Kellomäki S, Oker-Blöm P \& Kuuluvainen T (1985) The effect of crown and canopy structure on light interception and distribution in a tree stand: Crop physiology of forest trees. (ed. by PMA Tigerstedt, P Puttonen \& V Koski) Helsinki University Press, Helsinki, pp. 107-115.

Klimo E, Hager H, Matič S, Anič I \& Kulhavý J (2008) Floodplain forests of the temperate zone of Europe. Lesnická práce, Kostelec nad Černými lesy.

Körner C (1994) Biomass fractionation in plants: a reconsideration of definitions based on plant functions: A whole plant perspective on carbonnitrogen interactions (ed. by J Roy \& E Garnier) SBP Academic Publishing, The Hague, pp. 173185.

Kull O, Broadmeadow M, Kruijt B \& Meir P (1999) Light distribution and foliage structure in an oak canopy. Trees 14: 55-64. doi:10.1007/ s004680050209.

Lambert MC, Ung CH \& Raulier F (2005) Canadian national tree aboveground biomass equations. Canadian Journal of Forest Research 35: 1996 2018. doi:10.1139/x05-112.

Lehtonen A (2005) Estimating foliage biomass in Scots pine Pinus sylvestris and Norway spruce Picea abies plots. Tree Physiology 25: 803-811. doi:10.1093/treephys/25.7.803.

Liski J, Perruchoud D \& Karjalainen T (2002) Increasing carbon stocks in the forest soils of western Europe. Forest Ecology and Management 169: 159-175. doi:10.1016/S0378-1127(02)00306-7.

Mackenthun GL (2013) Elm losses and their causes over a 20 year period-a long-term study of ulmus in Saxony, Germany: The elms after 100 years of Dutch elm disease. Third International Elm Conference, October 9 - 11, 2013, Florence, Italy (ed. by R. Manzo) CNR-IPP Institute of Plant Protection, Italy.

Magee L (1990) $\mathrm{R}^{2}$ measures based on Wald and likelihood ratio joint significance tests. American Statistical Association 44: 250-253. doi:http://dx.doi.org/10.1080/00031305.1990.10475731.

Masera OR, Garza-Caligaris JF, Kanninen M, Karjalainen T, Liski J, Nabuurs GJ, Pussinen A, Jong BHJ \& Mohren GMJ (2003) Modeling carbon sequestration in afforestation, agroforestry and forest management projects: the CO2FIX V.2 approach. Ecological Modelling 164: 177-199. doi:10.1016/S0304-3800(02)00419-2.
Matula R, Damborská L, Nečasová M, Geršl M \& Šrámek M (2015) Measuring biomass and carbon stock in resprouting woody plants. PloS One 10: e0118388. doi:10.1371/journal.pone.0118388.

Nabuurs GJ, Garza-Caligaris JF, Kanninen M, Karjalainen $\mathrm{T}$, Lapvetelainen $\mathrm{T}$, Liski J, Masera $\mathrm{O}$, Mohren GMJ, Olgín M, Pussinen A \& Schelhaas MJ (2002) Manual of modelling framework for quantifying carbon sequestration in forest ecosystems and wood products. Alterra, Wageningen.

MZe ČR (2006) Zpráva o stavu lesa a lesního hospodáŕství České republiky v roce 2005. Ministerstvo zemedělství, Praha.

Nagelkerke NJD (1991) A note on a general definition of the coefficient of determination. Biometrika 78: 691-692. doi:http://links.jstor.org/sici?sic $\mathrm{i}=0006-3444 \% 28199109 \% 2978 \% 3$ A3\%3C691\% 3AANOAGD\%3E2.0.CO\%3B2-V.

Paine CET, Marthews TR, Vogt DR, Purves D, Rees M, Hector A \& Turnbull LA (2012) How to fit nonlinear plant growth models and calculate growth rates: an update for ecologists. Methods in Ecology and Evolution 3: 245-256. doi:10.1111/j.2041210X.2011.00155.x.

Parresol BR (1999) Assessing tree and stand biomass: a review with examples and critical comparisons. Forest Science 45: 573-593.

Peňáz J (1996) Trees classification: Silviculture in password (ed. by V Tesař) Ediční středisko MZLU $\mathrm{v}$ Brně.

Plíva K (1984) Typological classification of Czechoslovak forests. Lesprojekt, Brandys $\mathrm{n} / \mathrm{L}$.

Poleno Z \& Vacek S (2007) Silviculture I. Forest management based on ecological principles. Lesnická práce. Kostelec nad Černými lesy.

Pontailler JY, Ceulemans R, Guittet J \& Mau F (1997) Linear and non-linear functions of volume index to estimate woody biomass in high density young poplar stands. Annales des Sciences Forestières 54: 335-345. doi:http://dx.doi.org/10.1051/forest:19970402.

Quitt E (1971) Klimatické oblasti Československa. Studia Geographica 16. GU ČSAV v Brně, Academia, Praha.

R Development Core Team - R. (2012) A language and environment for statistical computing. Vienna, Austria: the R Foundation for Statistical Computing. http://www.R-project.org/.

Ruel JC, Larouche C \& Achim A (2003) Changes in root morphology after precommercial thinning in balsam fir stands. Canadian Journal of Forest Research 33: 2452-2459.

Santini A, La Porta N, Ghelardini L \& Mittempergher L (2008) Breeding against Dutch elm disease adapted to the Mediterranean climate. Euphytica 163: 45-56. doi:10.1007/s10681-007-9573-5. 
Seidel D, Leuschner Ch, Scherber Ch, Beyer F, Wommelsdorf T, Cashman MJ \& Fehrmann L (2013) The relationship between tree species richness, canopy space exploration and productivity in a temperate broad-leaf mixed forest. Forest Ecology and Management 310: 366-374. doi:http:// dx.doi.org/10.1016/j.foreco.2013.08.058.

Shipley B \& Meziane D (2002) The balanced-growth hypothesis and the allometry of leaf and root biomass allocation. Functional Ecology 16: 326-331. doi:10.1046/j.1365-2435.2002.00626.x.

Schulze ED, Schilling K \& Nagarajah S (1983) Carbohydrate partitioning in relation to whole plant production and water use of Vigna unguiculata L.Walp. Oecologia 58: 169-177. doi:10.1007/ BF00399213.

Schroeder P, Brown S, Mo J, Birdsey R \& Cieszewski C (1997) Biomass estimation for temperate broadleaf forests of the United States using inventory data. Forest Science 43: 424-434.

Sperry JS, Adler FR, Campbell GS \& Comstock JP (1998) Limitation of plant water use by rhizosphere and xylem conductance: results from a model. Plant, Cell and Environment 21: 347-359. doi:10.1046/j.1365-3040.1998.00287.x.

Staněk Z (1997) Physical aspects of resistivity measurements in plants from viewpoint of their ecological applications. Habilitation work, Department of Physics, Technical Univ. Prague, Czech Republic.

Šály R. 1978. Póda - základ lesnej produkcie. Příroda, Bratislava.

Šrámek M \& Čermák J (2012) The vertical leaf distribution of Ulmus laevis Pall. Trees 26: 1781-1792. doi:10.1007/s00468-012-0747-y.

Thimonier A, Šedivý I \& Schleppi P (2010) Estimating leaf area index in different types of mature forest stands in Switzerland: a comparison of methods. European Journal of Forest Research 129: 543-562. doi:10.1007/s10342-009-0353-8.
Urban J, Tatarinov F, Nadezhdina N, Čermák J \& Ceulemans R (2009) Crown structure and leaf area of the understorey species Prunus serotina. Trees 23: 391-399. doi:10.1007/s00468-0080288-6.

Urban J, Bequet R \& Mainiero R (2011) Assessing the applicability of the earth impedance method for in situ studies of tree root systems. Journal of Experimental Botany 62: 1857-1869. doi:10.1093/ $\mathrm{jxb} / \mathrm{erq} 370$.

Vašíček F (1980) Consequences of changes in water regime on ecological conditions, structures and biomass of understory layer of plants and shrubs in the ecosystem of floodplain forest in southern Moravia. Research Report No. VI-2-2/5-1. University Agricultural, Brno.

Viewegh J, Kusbach A \& Mikeska M (2003) Czech forest ecosystem classification. Journal of Forest Science 49: 74-82.

Vincent M, Krause C \& Zhang SY (2009) Radial growth response of black spruce roots and stems to commercial thinning in the boreal forest. Forestry 82: 557-571.

Vose JM, Sullivan NH, Clinton BD \& Bolstad PV (1995) Vertical leaf area distribution, light transmittance, and application of the Beer-Lambert Law in four mature hardwood stands in the southern Appalachians. Canadian Journal of Forest Research 25: 1036-1043. doi:10.1139/x95-113.

Vyskot M (1976) Tree story biomass in lowland forests in South Moravia. Rozpravy ČSAV 86. Academia, Praha.

Webber JF \& Gibbs JN (1984) Colonization of Elm Bark by Phomopsis oblonga. Transactions of the British Mycological Society 82: 348-352.

Wilhelm GJ \& Rieger H (2013) Naturnahe Waldwirtschaft - mit der QD-Strategie. Eugen Ulmer KG, Stuttgart.

Zlatník A (1976) Forest phytocenology. SZN, Praha. 